\title{
The Development of Learning Evaluation Management in Utilizing ICT Systems in Primary School Around Banda Aceh City
}

\author{
Hazal Fitri ${ }^{1}$, Irfandi ${ }^{2}$, Murniati ${ }^{3}$, Nasir Usman ${ }^{4}$ \\ ${ }^{1234}$ STKIP Bina Bangsa Getsempena Banda Aceh, Indonesia \\ hazalsaleh@yahoo.com
}

\begin{abstract}
This research study aims to design the development of a suitable learning evaluation management model in the utilizing of the Banda Aceh Primary School Information Communication Technology (ICT) system, to develop what learning evaluation management model is suitable for utilizing Information Communication Technology (ICT) systems level of Primary School in Banda Aceh City. Then aims to improve the performance of the development of learning evaluation management models in the utilization of the Information Communication Technology (ICT) system at the Primary School level in Banda Aceh, providing a place for relatively new developing lecturers/ research groups in research capabilities to be able to utilize the facilities and expertise, and adopt and imitate a good research culture from a group of researchers who are more advanced in other universities in carrying out quality research. The program also aims to build research collaboration between universities in Indonesia. The method used in this research is development research (research and development version of Borg and Gall, 1983). The expected benefits in this research study are that all teachers who teach at the elementary school level can use / utilize the Information Communication Technology (ICT) system in the learning process, this is to improve the quality of education at that level.
\end{abstract}

Keywords : development; management; evaluation; ICT System.

\section{Introduction}

Teacher is the most decisive component in education system as a whole, which must receive central, first, and primary attention. Teacher is a figure who is always a strategic spotlight when talking about education, because teacher is always associated with any component in education and it is the most influential component in creating quality education processes and outcomes. In Law No. 14 of 2005 concerning Teachers and Lecturers it was stated that "teachers are professional educators with the main task of educating, teaching, guiding, directing, training, evaluating and evaluating students in early childhood education in formal education, basic education, and middle education."

Information technology or Information and Communication Technology (ICT) has brought changes in various sectors, included as learning media for students. According to Simarmata (2007: 3) that "Information technology is used refers to a variety of systems and capabilities used in making, storing, and distributing data and information. The main components are three, computer, communication and skills. The Importance and fundamental changes to ICT management, the process of changing the mindset about media in learning, namely the provision of collections held to the concept of "not must have" but can "provide information", ease of delivery of information, And it will be more easy to be realized with the existence of ICT. Then the concept of time efficiency in learning and delivering material have a very big role in the world of education today.

In addition to learning media in the form of libraries, the environment, cheap teaching aids (APM), factory product teaching aids are now also developing learning media such as 
television, radio, compact disks (CD) learning, laptops and projectors which is called Information Communication Technology (ICT) devices which provides convenience and flexibility in presenting learning in the classroom. Therefore the development of learning based on Information Communication Technology (ICT) or information and communication technology for teachers, able to help teacher's work in teaching through effective and efficient functions and systems.

Phenomena that occur in the field, according to observations of researchers in a number of Elementary Schools (SD) inBanda Aceh City that more than $70 \%$ of teachers in these schools have used Information Communication Technology (ICT) in the learning process, this ability is obtained after teachers in Elementary Schools (SD) have been trained several times to use Information Communication Technology (ICT) as learning media in Information Communication Technology (ICT) training programs such as training in limited use of computers in classrooms, What is Active Learning (WIAL), Intel Teach Program and Developing active learning with ICT's (DALI) by DBE2 USAID Aceh in collaboration with Universoty of Syiah Kuala and Education, Youth, and Sport Office of Banda Aceh city.

Based on the problems above, a research study is needed to see how to develop a learning evaluation management model in utilizing the Elementary School (ICT) Information Communication Technology (ICT) system as a learning medium by teachers in the classroom, so researchers are interested in conducting research entitled " The Development of Learning Management Models in Utilizing ICT Systems in Primary Schools in Banda Aceh City".

\section{Literature Review}

Management in the broadest sense defines as planning, organizing, directing, and controlling (P4) organizational resources to achieve goals effectively and efficiently. Management in the narrowest sense defines as school / madrasah management which includes school / madrasah program planning, school / madrasah program implementation, school / madrasah leadership, supervisor / evaluation and school / madrasah information system. According Murniati AR (2008: 71) "Management is the activity of regulating various resources, both human and material, in order to carry out various activities of an organization to achieve goals optimally. Therefore, management is the duty of the leadership in moving various existing sources towards the goals to be achieved.

\section{Methodology}

The research methods used are as follows:

a. Types and Character of Research. A model development refers to a group of methods that emphasize qualitative and quantitative analysis (Yin, 2009: 57). Data is collected from a number of organizations through methods, such as participant-observation, indept-interviews, and longitudinal studies. The case study approach seeks an understanding of a problem that is being investigated. Providing opportunities to ask questions and capture the wealth of organizational behavior, but conclusions that are described are specific to the particular organization being studied and may not be generalized.

b. The research approach used a development research (R and D) version of Borg and Gall 1983. 
c. The research location covered all elementary schools in Banda Aceh City. The location taken by considering that the schools in Banda Aceh City are representatives of each primary school in Aceh as the example, and as model for other primary schools in each district / city.

d. Types and Data Sources. In this study the data needed covers primary data or secondary data. Primary data is data obtained from direct or first-hand data sources, is needed to discuss technical-economic feasibility (feasibility study), master plan for developing learning management development models in theutilization of elementary-level Information Communication Technology (ICT) systems throughout Banda Aceh Borg and Gall 1983 including all elementary schools in Banda Aceh City and the Education Office were institutions that were concerned with the quality of the progress of their schools. Then secondary datais the type of data that is not collected researchers itself (Marzuki, 2002: 45). Secondary data can be in the form of an information value from the evaluation process. Then the report on the results of previous research and others publication. Secondary data sources contain teaching materials, international journals, secondary and tertiary.

e. Data collection instruments are divided into two, first for primary data using interview techniques and questionnaires. This interview technique is done by indept-interwiew, the type of method of collecting data through interviews conducted in depth that is conveyed to the data source (W. Gulo, 2003). Besides that, to givea further accurate and elaboration of data is carried out by Focus Group Discussion (FGD) by involving stakeholders.

f. Data analysis.

\subsection{Research Results}

\section{Results And Discussion}

The process of collecting data, the research team conducted three activities, first is interviews, second is documentation observation, and the last one is development of Information Communication Technology (ICT) based learning models. Observation activities are carried out and adjusted to the teaching schedule of the subject and subject lesson during the observation. The process of data retrieval is done by referring to the instruments that have been prepared, interview guidelines, observation guidelines and documentation guidelines. To describe the description of learning management carried out by ICT teachers of SD Negeri 19, SD Negeri 23, SD Negeri 24 Kota BandaAceh, the following data are presented in the research results.

\section{a. Learning Planning in the Utilization of ICT in Primary Schools in Banda Aceh}

Learning planning prepared by the teacher in utilizing the Information Communication Technology (ICT) system in SD Negeri 19, SD Negeri 23, SD Negeri 24 Kota Banda Aceh, is by arranging a number of learning devices. The device was collected to be signed by the principal. The device is then returned to the teacher. The devices arranged include effective weeks, Annual Programs (Prota), Semester Programs (Prosem), Syllabus and Learning Implementation Plans (RPP). Learning plans compiled by teachers in utilizing Information Communication Technology (ICT), based on the school-based curriculum (SBC), are guided by the National Education Standards Agency (BNSP). As the results of interviews with teachers of SD Negeri 19, SD Negeri 23, SD Negeri 24 Kota Banda Aceh, that: 
Each teacher must make a learning device before teaching. In this school, we hand over learning tools to principals at the beginning of each semester in the form of effective weeks, Annual Programs (Prota), Semester Programs (Prosem), Syllabus and Learning Implementation Plans (RPP).

Before the annual program and semester program are arranged, the first step they take is to make the details of the week effective each semester. Effective week details are based on the education calendar to find out the number of effective lesson hours, then allocated to each competency standard (CS) and basic competencies (BC) in the annual program/semester program.

The annual program which is compiled includes Competency Standards (CS) and Basic Competencies (BC) which must be mastered by students after studying certain subjects, time allocation and information. The semester program is an elaboration of the annual program containing outlines about the things that will be implemented and achieved in the semester. While the semester program contains about the month, Competency Standards (CS), Basic Competencies (BC), indicators, and subject matter to be conveyed, as well as time allocation. Programs arranged beside the annual program and semester programs are Syllabus and Learning Implementation Plans (RPP). Syllabus includes CompetencyStandards (CS), Basic Competencies (BC), learning materials, learning activities, indicators of achievement, assessment, time allocation, and learning resources. The preparation of the syllabus is based on the syllabus model developed by the National Education Standards Agency (BNSP), however, the syllabus model is not absolutely They directly use, but is modified again in accordance with school conditions. They still adopted the syllabus model from the National Education Standards Agency (BNSP), and the Ministry of National Education, then the syllabus model was reviewed and adjusted to the conditions of the school. The following are the results of interviews with teachers regarding writing syllabus on ICT subjects. This is in accordance with the statement of the ICT teacher of the 19th Elementary School, SD 23, Banda Aceh Elementary School 24, that:

The statement of the ICT teacher at SD Negeri 19, SD Negeri 23, SDNegeri 24 Kota Banda Aceh was almost the same as the other teachers that the syllabus used was the syllabus of the Ministry of National Education in 2007 which was obtained from the internet and adjusted to the conditions in this school. The statement of the teachers was strengthened by the statement of the head of SD Negeri 19, SD Negeri 23, SD Negeri 24 Kota Banda Aceh, as follows:

Computer Information Technology (ICT) is a basic lesson and must be taught to students. Based on whatis written in the content of standard which states that one component in the elementary curricula structure contains ICT subjects. The school also empowers other subject matter teachers who have the skills and abilities to teach these subjects. This condition does not become an obstacle for ICT teachers in teaching preparation,because nowadays there are many sources such as the internet that provide guidelines for preparing syllabus and Learning Implementation Plans (RPP), so it is not a problem if they adopt the syllabus model and Learning Implementation Plan )from other schools while paying attention to the conditions in this school. While others such as the annual program and semester program adjust to the models here.

The learning plan program is arranged in the form of a Learning Implementation Plan (RPP) containing the subject identity, time allocation, indicator 'competency standards', learning objectives, subject matter or learning, methods, learning strategies, learning 
resources, and assessment. Learning Implementation Plans (RPP) are made by referring to the syllabus and arranged into one for several face-to-face meetings, this is due to the linkages of several indicators as learning objectives to be achieved.

\section{b. Learning Implementation in the Usef of ICT}

The process of implementing learning carried out by teachers in Elementary School (SD) 19, Elementary School 23, SDNegeri 24 Kota Banda Aceh. In using ICT, not all teachers conducted based on planning due to media limitations. The activities carried out are opening lessons, delivering material, students doing practical activities and closing learning. The following are the learning activities carried out by teachers in utilizing Information Communication Technology (ICT) in Elementary School 19, Elementary School 23, Primary School 24, Banda Aceh City.

\section{- Preliminary activities}

In the initial stage, the teacher starts by preparing the media in the form of laptops and projector, then the teacher starts talking about the previous material. At that time, the teacher asks questions about the past material to check students' understanding. Next the teacher notifies the material learned at that time and conveys the learning objectives so that students focus on what abilities they will get from the learning itself.The activity is carried out in only about 10-15 minutes.

\section{- Core activities}

At the core activity the teacher tells the strategy or steps of learning that will be used, with the aim that students focus more on the goals to be achieved. The next activity the teacher presents learning material using laptop and infocus media. When the author makes observations, the material taught is typing correctly in Microsoft Word programs. In delivering the material, the researchers found that the teacher applied the question and answer method, demonstration, direct learning, and practice and assignment. Although the teacher has used various methods, but still uses the lecture method as an introduction to the material. In general, teachers who use the Information Communication Technology (ICT) system present material with direct learning methods, because based on the author's observations, students' understanding of the material is easier to accept if the theory is given simultaneously with practice. The following are the results of interviews relating to the use of learning methods or strategies in the process of learning ICT subjects in Elementary School 19, Elementary School 23, Primary School 24, Banda Aceh City.

In learning to use ICT, student's activity is highly prioritized. The lecture method I use when explaining the materialis,then followed by showing the steps and the students working on a good assignment in the lab or outside the lab. I still use lectures because to teach students, if I am not lecturing students will experience difficulties. Sometimes if the material is easy I often practice directly in the laboratory and students follow it, but if in class, Students only pay attention on the theory. Then students practice in the laboratory.

\section{- Closing Activity}

At the end of the lesson the teacher notifies the material that will be discussed at the next meeting. In addition, the teacher gives the task of reading or working on the questions from the textbook and the internet relating to the material that has been taught or that will be learned. The teacher reaffirms the material that has been taught if time is stillsufficient, this occurs because the practice takes more time, so the teacher does not have the time to draw conclusions. The statement expressed by one teacher is as follows: 
Practice takes a lot of time, because I have to pay attention to one by one student work and give guidance privately. I veryappreciate the work of students, so they are never lazy to work on their duties. So it is impossible for me to give classical guidance such as giving lessons in class. This kind of conditions make me sometimes not able to draw conclusions, but I only emphasize the important things related to the practices they have done. I just ask them to read the material again and tell the material to be studied later.

After carrying out the evaluation, the teacher inputs the students' scores into the book grade list. Students who get low score are given remedial. Remedial is done by giving additional tasks to be done at home and there is also a form of repetition of the material first. Some teachers provide remedials at the end of the semester and there are also teachers who provide remedial to students who have not completed any Basic Competencies (KD). While students who have been completed are given enrichment and there are also teachers giving freedom for students to take exams again or not.

\subsection{Discussion}

The results of this research, discussed in this section conceptually based on theories that have been presented in the substance of chapter II and other learning management concepts which include: learning programs, implementation of learning, and evaluation of learning outcomes.

\section{a. Learning Planning in Utilizing ICT in Primary Schools in Banda Aceh}

Based on the results of the study, it can be concluded that before carrying out learning, compiling learning devices is a must. The device is collected to be signed by the principal, then returned to the teacher concerned. Devices compiled include effective weeks, Annual Programs (Prota), Semester Programs (Prosem), Syllabus and Learning Implementation Plans (RPP).

Planning that is compiled by ICT teachers at Elementary School (SD) 19, SD Negeri 23, SD Negeri 24 Kota Banda Aceh, this has shown good performance, because as a profession, teachers are required to have the ability to plan learning. The ability to plan learning is very important because this planning is the beginning of a series of teaching and learning activities. Without good planning, the implementation of learning tends not to be directed and not orderly which will have an adverse effect on learning outcomes.

Learning planning is an activity to formulate the goals to be achieved by a teaching activity, what methods are used to assess these objectives, the materials to be delivered, how to deliver it, and what tools or media are needed. Learning planning is the notes of the teacher's initial thoughts before managing the learning process. Still in the same source, learning planning is the preparation of teaching which contains things that need to or must be done by teachers and students in carrying out learning activities which include elements of material selection, methods, media, and evaluation tools. Suryosubroto (2010: 22) suggests "planning is the selection of a number of alternatives regarding the establishment of procedures for achievement, as well as estimates of the sources that can be provided to achieve these goals". What is meant by source includes human resources, material, money, and time. In planning, we know several stages, namely: (a). Identification of problems, (b) formulation of problems (c) goal setting, (d) identification of alternatives, (e) selection of alternatives, and (f) alternative elaboration. " 
Learning seems to give a better or deeper impression, which is to foster the desire to learn in students. While teaching seems to be more focused on the process of transferring knowledge from teachers to students. As for students who understand or not, are motivated to learn independently or not, they are not included in the values of teaching. This is in accordance with the opinion expressed by Hamalik (2010: 135) that "Good teachers will try as much as possible so that the teaching is successful. One of the factors that can bring success, is that the teacher always makes teaching plans beforehand ". Learning planning is an important step to achieving success. If the learning plan is arranged well it will make learning goals can be achieved effectively and efficiently. Learning planning plays an important role in guiding teachers to carry out their professional duties as educators in serving the learning needs of their students. Teaching planning is also intended as aninitial step before the learning process takes place.

\section{b. Learning Implementation in the Use of ICT in Primary Schools in the City of Banda Aceh}

Daily learning is carried out by using three stages of activity, known as opening / beginning / preliminary activities, core activities and closing activities. The following is described in detail about the discussion of research results.

\section{- Introduction Stage}

The results of the study indicated that at the preliminary stage the teacher did attendance, motivation and informs the learning objectives. The teacher asked questions about the past material to check students' understanding. Then the teacher informed the material learned at that time and presented the learning objectives so that students focus on what abilities they will get from the learning itself. The activity was carried out in only about 10-15 minutes.

Telling students the goals or abilities they are expected to master after the learning process takes place. Telling students what activities will be carried out during the learning process. If necessary, tell them about the learning resources that can be used. The activity of preparing students directly related to the material to be discussed is called the initial learning activity. Meanwhile activities that were not directly related to the material or competencies to be discussed are called pre-learning activities. Opening the lesson is an activity carried out by the teacher to create mental readiness and attract the attention of students optimally, so that they focus fully on the lessons to be presented. For this purpose, Mulyasa (2009: 84) said that teachers can make the following efforts:

a. Linking material that has been studied with the material to be presented.

b. Conveying the objectives to be achieved and the outline of the material tobe studied (in certain cases, goals can be formulated with students).

c. Delivering the steps of learning activities and tasks that must be completed to achieve the objectives that have been formulated.

d. Utilizing media and learning resources that are in accordance with the material presented.

e. Asking questions, both to find out students' understanding of the lessonsthat have been and to explore theinitial abilities related to the material to be learned.

Apperception (making a link) is one way to attract students' attention to the material to be discussed by creating a connection. Students will be interested in the material that will be learned if they see the relationship with their previous experience or according to their 
interests and needs. Asking questions about lesson material that are related and have been studied before. Guiding students to express experiences related to the material that will be discussed if there is one. Telling about the benefits obtained from the material to be learned. According to Rianto (2010: 132) that "Apperception is a brief review of the previous material." Apperception includes: the activity of asking questions to link the material to be taught with the material or knowledge that has been mastered by the students before, giving comments on the answers given by students arouse the motivation and attention of students to take part in learning activities.

This activity emphasizes more on how far the initial abilities that students have. And the teacher needs to connect the subject matter that students already had with the material that students will learn. By not ignoring the provision of learning motivation towards students. These activities are a series that need to be developed at the beginning of learning.

\section{- Core activities}

The results of the study indicate that the teacher notifies the strategies or steps of learning that will be used, with the aim that students focus more on the objectives to be achieved. In delivering the material, the teacher applies the question and answer method, demonstration, direct learning, and practice and assignment. The material taught about how to type correctly in Microsoft Word.

In core activities focused on activities aimed at developing reading, writing and arithmetic abilities. Presentation of learning materials is carried out using various strategies / methods that are varied and can be done in classical, small groups, or individuals. The core activities in learning are the main activities in the learning process or in the process of mastering students' learning experiences.

\section{- Closing Activity}

The results showed that at the end of the lesson the teacher notified the material to be discussed at the next meeting, gave the task of reading or working on the questions from the textbook and the internet related to the material that had been studied, reaffirming the material that had been taught and the teacher concluding the students.

The final activity in learning is not only interpreted as an activity to close the lesson, but also as an activity to assess student learning outcomes and follow-up activities. Follow-up activities must be taken based on the process and student learning outcomes. The activity of closing the lesson is an activity carried out by the teacher to find out the achievement of the goals and understanding of the students on the material that has been studied, and to end the learning activities. For this purpose, Mulyasa (2009: 84) said that teachers can make the following efforts:

a. Drawing conclusions about the material that has been studied (conclusions can be made by the teacher, students at the request of the teacher, or by students and teachers).

b. Asking several questions to measure the level of achievement of objectives and effectiveness of the learning that has been carried out.

c. Delivering deepening material that must be learned, and tasks that must be done (both individual assignments and group assignments) according to the subject matter that has been studied.

To obtain the right information in evaluation activities is carried out through measurement activities. Measurement is a process of giving scores or numbers to a situation or symptom based on certain rules. Thus there is a close relationship between measurement 
(measurment) and evaluation (evaluation) measurement activities are the basis of evaluation activities.

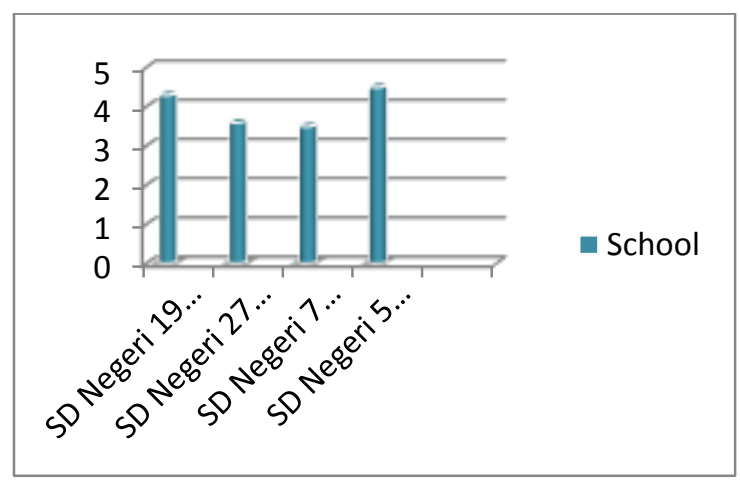

\section{Conclusion}

Based on the results of the research and discussion, it can be concluded that:

1. Model development planning compiled by teachers of SD Negeri 19, SD Negeri 23, SD Negeri 24 Kota Banda Aceh, in utilizing ICT systems is based on the schoolbased Curriculum (KTSP) be guided on the National Education Standards Agency (BNSP). Learning tools in the utilization of ICT systems are only prepared by teachers in grades IV, V and VI in the fields of Mathematics, Natural Sciences, Social Sciences and ICT. They are handed over to the principal at the beginning of each semester to be signed. Devices compiled include effective weeks, Annual Programs (Prota), Semester Programs (Prosem), Syllabus and Learning Implementation Plans (RPP).

2. The process of implementing the learning model developed by elementary school teachers (SD) 19, SD Negeri 23, SD Negeri 24 Kota Banda Aceh in utilizing ICT has not been fully implemented based on the plans that have been prepared. This is due to media limitations and inappropriate implementation times. Learning activities have not been fully implemented systematically through the process of exploration, elaboration and confirmation. In the preliminary activities the teacher does attendance, apperception, motivates students and notifies the learning objectives. At the core activity, the teacher applies the question and answer method, demonstration, direct learning, practice and assignment. At the end of the lesson the teacher notifies the material to be discussed at the next meeting, gives the assignment, reiterates the material that has been taught and the teacher and the students draw conclusions.

\section{Acknowledgement}

In this segment the author would like to express his deepest gratitude to:

1. For teachers and principals of SD Negeri 19, SDNegeri 23, SD Negeri 24 Kota Banda Aceh.

2. The head of the education and culture office of the city of Banda Aceh.

3. To colleagues and colleagues who have contributed a lot in carrying out in facilitating.

4. To the STKIP campus, Build Nation Getsempena Banda Aceh. 
5. To the Directorate General of Higher Education (DRPM) of Higher Education which has provided funding for the Inter-University Cooperation Research (PKPT).

\section{References}

Darjanto. 2007. Teaching Planning for Primary Schools.PT. Inna Publikatama. Jakarta.

Hamalik. 2008. Communication Technology \& Learning Information. Akasara Earth. Jakarta.

Harjanto. 2010. Teaching Planning. PT. Rieneka Cipta. Jakarta.

Moleong, Lecxy J. 2006. Qualitative Research Methodology. CV.Youth Rosda Karya. Bandung.

Mulyana.(2008). Qualitative Research Methodology. Bandung: Teenager Rosdakarya.

Murniati, AR. 2008. Strategic Management.The Pioneering Media Library. Bandung.

Minister of National Education Regulation Number 20 of 2007 concerning Educational Assessment Standards.Jakarta: Directorate General of Primary and Secondary Education Management.

Rianto, Yatim in Muhaimin. 2010. New Learning Paradigm. Prenada Media.Jakarta.

Rusman. 2009. Curriculum Management. PT. Raja Grafindo Persada. Jakarta.

Sa'ud, Udin Syaefudin. 2009. Educational Innovation. Alfabeta. Bandung.

Simarmata. 2007. Learning Management for Primary Schools. Graphic Media. Surabaya.

Sugiyono. 2007. Educational Research Methods (Quantitative, Qualitative and $R \& D$ Approaches). Alfabeta. Bandung.

Suryosubroto. 2010. School Education Management. Rineka Cipta. Jakarta.

Suwardi. 2007. Learning Management. Graphic Media. Surabaya.

Usman, Nasir. 2012. Management of Teacher Performance Quality Improvement (Concept, Theory, and Model). Citapustaka Pioneer Media. Bandung.

Law of the Republic of Indonesia Number 14 of 2005 concerning Teachers and Lecturers of National Education Standards. Jakarta.

Uno, B Hamzah and Nina Lamatenggo.2010. Communication Technology \& Learning Information. Akasara Earth. Jakarta.

Yamin, Martinis and Maisah. 2009. Classroom Learning Management (Strategy to Improve Learning Quality).Gaung Persada. Jakarta.

Uno, B Hamzah and Nina Lamatenggo.2010. Communication Technology \& Learning Information.Akasara Earth. Jakarta.

Yamin, Martinis and Maisah. 2009. Classroom Learning Management (Learning Quality Improvement Strategies). Gaung Persada. Jakarta. 